\title{
GMR
}

\section{Maize endophytic bacteria as mineral phosphate solubilizers}

\author{
C.S. de Abreu ${ }^{1}$, J.E.F. Figueiredo ${ }^{2}$, C.A. Oliveira ${ }^{2}$, V.L. dos Santos ${ }^{3}$, E.A. Gomes ${ }^{2}$, \\ V.P. Ribeiro ${ }^{1}$, B.A. Barros ${ }^{2}$, U.G.P. Lana ${ }^{2}$ and I.E. Marriel ${ }^{1,2}$ \\ ${ }^{1}$ Programa de Pós-Graduação em Ciências Agrárias, \\ Departamento de Ciências Agrárias, Universidade Federal de São João Del Rei, \\ Sete Lagoas, MG, Brasil \\ ${ }^{2}$ Laboratório de Microbiologia e Biologia Molecular, Embrapa Milho e Sorgo, \\ Sete Lagoas, MG, Brasil \\ ${ }^{3}$ Laboratório de Microbiologia e Biologia Molecular, \\ Departamento de Microbiologia, Instituto de Ciências Biológicas, \\ Universidade Federal de Minas Gerais, Belo Horizonte, MG, Brasil \\ Corresponding author: I.E. Marriel \\ E-mail: ivanildo.marriel@embrapa.br \\ Genet. Mol. Res. 16 (1): gmr16019294 \\ Received September 15, 2016 \\ Accepted December 7, 2016 \\ Published February 16, 2017 \\ DOI http://dx.doi.org/10.4238/gmr16019294
}

Copyright (C) 2017 The Authors. This is an open-access article distributed under the terms of the Creative Commons Attribution ShareAlike (CC BY-SA) 4.0 License.

ABSTRACT. In the present study, we demonstrated the in vitro
activity of endophytic phosphate-solubilizing bacteria (PSB). Fifty-five
endophytic PSB that were isolated from sap, leaves, and roots of maize
were tested for their ability to solubilize tricalcium phosphate and
produce organic acid. Partial sequencing of the $16 \mathrm{~S}$ rRNA-encoding
gene showed that the isolates were from the genus Bacillus and
different species of Enterobacteriaceae. The phosphate solubilization
index on solid medium and phosphate solubilization in liquid medium
varied significantly among the isolates. There was a statistically
significant difference $(\mathrm{P} \leq 0.05)$ for both, the values of phosphate-
solubilizing activity and $\mathrm{pH}$ of the growth medium, among the isolates.
Pearson correlation was statistically significant $(\mathrm{P} \leq 0.05)$ between
P-solubilization and $\mathrm{pH}(\mathrm{R}=-0.38)$, and between the gluconic acid

Genetics and Molecular Research 16 (1): gmr16019294 
production and the lowering of the $\mathrm{pH}$ of the liquid medium at $6(\mathrm{R}=$ $0.28)$ and 9 days $(\mathrm{R}=0.39)$. Gluconic acid production was prevalent in all the PSB studied, and Bacillus species were most efficient in solubilizing phosphate. This is the first report on the characterization of bacterial endophytes from maize and their use as potential biofertilizers. In addition, this may provide an alternative strategy for improving the phosphorus acquisition efficiency of crop plants in tropical soils.

Key words: Zea mays; Endophytic bacteria; Phosphate-solubilizing bacteria; Organic acids

\section{INTRODUCTION}

The use of phosphate fertilizers (P-fertilizers) is essential for providing phosphorus as a nutrient for healthy plant growth (Pinto et al., 2013). The majority of the fertilizer-derived phosphorus is retained in the solid phase of the soil as precipitates with aluminum, iron, calcium, and organic matter or is adsorbed on the surface of clay particles, which makes it unavailable for plant uptake (Hinsinger, 2001; Novais et al., 2007; Gurikar et al., 2016). The use of natural sources of phosphate fertilizers is limited by the low ion-exchange capacity of the acidic tropical soils (Edwards et al., 2016). In addition, soluble phosphate chemical fertilizers are costly and may cause eutrophication. Phosphate-solubilizing bacteria (PSB) could play an important role in supplying phosphate to plants in an eco-friendly and sustainable way (Oliveira et al., 2009; Gomes et al., 2014).

PSB, also referred as phosphobacteria, are found ubiquitously in soil and their numbers vary depending on the type of soil (Mohammadi, 2012). PSB can solubilize phosphorus from organic and inorganic sources by the action of organic acids and extracellular enzymes that are secreted into the soil (Chen et al., 2006; Park et al., 2011; Baliah et al., 2016; Gurikar et al., 2016). PSB releases low molecular weight organic acids, which solubilizes mineral phosphates and reduces the $\mathrm{pH}$ of soil (Goldstein, 1986; Whitelaw, 2000; Pérez et al., 2007; Gomes et al., 2014). PSB have been widely tested as biofertilizers and inoculants to increase crop yield (Karpagam and Nagalakshmi, 2014). Currently, different species of bacteria such as Azotobacter chroococcum, Bacillus subtilis, Bacillus cereus, Bacillus megaterium, Arthrobacter ilicis, Escherichia coli, Pantoea agglomerans, Pseudomonas putida, Pseudomonas aeruginosa, Enterobacter aerogenes, Microbacterium laevaniformans, and Micrococcus luteus have been identified as P-fertilizers (Kumar et al., 2014).

Endophytic PSB is more competitive than non-endophytic or facultative microorganisms inside the host plant since the endophyte-plant interaction is the result of an evolutionary process that is controlled by genes of both organisms (Rosenblueth and MartínezRomero, 2006). In fact, almost all endophytes represent a group of soil bacteria, which can colonize plants without inducing the host defense pathway. Thus, the distinction between free-living soil bacteria, the rhizosphere population, and endosymbionts of a host plant may represent a true continuum, with microbes able to move between the soil, the rhizosphere, and inside the root (Farrar et al., 2014). Indeed, several species of Bacillus and Pseudomonas use the nutrient niche in the rhizosphere and change from a free-living condition to an endophytic state (Rosenblueth and Martínez-Romero, 2006). Bacterial endophytes that were injected into stems moved to the roots and the rhizosphere, thereby confirming the existence of a continuous

Genetics and Molecular Research 16 (1): gmr16019294 
shift in microbial community within the root microbiome (Gaiero et al., 2013). Furthermore, bacterial endophytes can be transported from the seeds into the roots and tissues, reducing the need of continuous inoculations (Johnston-Monje and Raizada, 2011). However, the ability of endophytic bacteria to solubilize phosphates in tropical and sub-tropical soils is not well-studied.

The main goals of the present study were to isolate and characterize endophytic PSB from maize and to test their ability of solubilizing tricalcium phosphate (TCP) in vitro.

\section{MATERIAL AND METHODS}

\section{Experimental sites and isolation of endophytic bacteria}

This study was carried out in 2013, at Embrapa Maize and Sorghum Research Center, Sete Lagoas, Minas Gerais State, Brazil.

Leaves and roots of maize plants were disinfected according to the method described by Araújo et al. (2000), macerated in liquid nitrogen, diluted with $0.85 \%$ sodium chloride $(\mathrm{w} / \mathrm{v})$ and homogenized for $30 \mathrm{~min}$. The sap samples extracted under positive pressure were diluted with saline solution prior to inoculation (Figure 1). All samples were pre-selected by incubation at $25^{\circ}-28^{\circ} \mathrm{C}$ for up to 10 days on the National Botanical Research Institute phosphate (NBRIP) solid medium (Nautiyal, 1999).

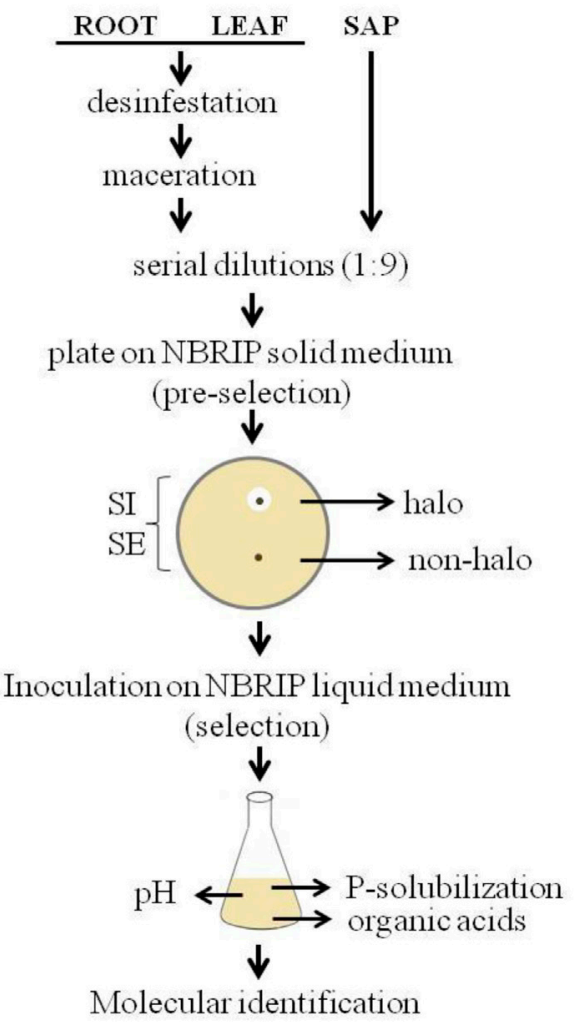

Figure 1. Schematic representation of the protocol used for selecting maize PSB using the NBRIP medium.

Genetics and Molecular Research 16 (1): gmr16019294 


\section{Determining the phosphate-solubilizing efficiency of endophytic bacteria on NBRIP solid medium}

The selected isolates were tested for their ability to solubilize phosphate on NBRIP agar containing $40 \mathrm{~g} / \mathrm{L}$ dextrose and TCP as the sole source of phosphate. The phosphate solubilization index (SI) was estimated by the following equation: SI $(\mathrm{mm})=$ (halo zone + colony diameter) / colony diameter. The isolates were classified as low (SI $<2)$, middle $(2<$ $\mathrm{SI} \leq 4)$, and high solubilizer (SI $>4$ ) according to Berraquero et al. (1976).

\section{Determining the phosphate-solubilizing efficiency of endophytic bacteria in NBRIP liquid medium}

Aliquots of $0.1 \mathrm{~mL}$ of each isolate cultured in trypticase soy broth were incubated and subsequently transferred to the NBRIP medium containing $40 \mathrm{~g} / \mathrm{L}$ glucose and incubated with stirring at a temperature of $30^{\circ} \mathrm{C}$. The optimum times of incubation for maximum phosphate solubilization were six and nine days as revealed by previous tests (data not shown). The $\mathrm{pH}$ values were measured in water and the phosphorus content released in the culture supernatants was determined by the ammonium molybdate colorimetric method.

\section{Quantification of organic acid production by maize endophytic bacteria}

Organic acids were quantitated by high-performance liquid chromatography; a $30 \mathrm{~cm}$ x $7.8 \mathrm{~mm}$ Supelcogel C-610H column (Sigma-Aldrich, St. Louis, IL, USA) was used in the Shimadzu Prominence Model LC-20A (Shimadzu, Japan) apparatus. The separation of acids occurred at $65^{\circ} \mathrm{C}$ with $5 \mathrm{mM} \mathrm{H}_{2} \mathrm{SO}_{4}$ as the mobile phase, at a flow rate of $0.6 \mathrm{~mL} / \mathrm{min}$. The Shimadzu RID-10A differential refractive index detector with the cell temperature at $45^{\circ} \mathrm{C}$ was used to measure the concentration of individual organic acids in the samples. The peak wavelength separation area generated by refractive index was calculated by using the standard curve for each acid.

\section{Molecular identification of maize endophytic bacteria}

Identification of the 55 selected PSB isolates by partial sequencing of the $16 \mathrm{~S}$ rRNA-encoding gene was performed with the bacterial universal primers F968 (5'-CGC CCG GGG CGC GCC CCG GGC GGG GCG GGG GCA CGG GGG GAA CGC GAA GAA CCT TAC-3') and R1401 (5'-CGG TGT GTA CAA GAC CC-3'). The PCR conditions used were according to that described in Figueiredo et al. (2009). The amplicons were purified using the QIAquick gel extraction kit (Qiagen, Hilden, Germany). Sequencing reactions were performed with the BigDye Terminator v3.1 Cycle Sequencing Kit according to the manufacturer instructions (Applied Biosystems, Foster City, CA, USA), and the reactions were run on an Applied Biosystems automatic sequencer ABI-3100 (Applied Biosystems). Sequence editing and contig sequences were generated with Clustal Omega (http://www.ebi. ac.uk/Tools/msa/clustalo/) and similarity among sequences was evaluated by the BLASTn program, which was run against all available DNA sequences deposited in the GenBank database (http://www.ncbi.nlm.nih.gov). Nucleotide sequences of bacteria were deposited in GenBank. 


\section{Statistical analysis}

The data were analyzed according to a randomized design with three replicates per sample, except for phosphate solubilization in solid medium, where four replicates were used per sample. The analysis of variance for each test was made using the Sisvar 5.3 program (Ferreira, 2010). Significant differences were analyzed by the F test $(\mathrm{P} \leq 0.05)$, and the means were compared using the Scott-Knott test at $5 \%$ probability. To verify the association between $\mathrm{P}$-solubilization and $\mathrm{pH}$, the Pearson correlation analysis was performed using the $\mathrm{R}$ software (http://www.R-project.org) at 5\% probability.

\section{RESULTS}

The maize endophytic PSB used in this study were pre-selected on NBRIP medium containing TCP. To assess the potential of PSB as bioinoculants, we evaluated the SI and phosphate-solubilizing efficiency (SE) on solid medium, and quantified the soluble phosphate and organic acids in liquid medium. The molecular identity of the isolates was determined by partial sequencing of the $16 \mathrm{~S}$ rRNA-encoding genes.

\section{Selection of maize endophytic PSB on solid NBRIP medium}

One hundred and fifteen cultivable endophytic bacteria isolated from roots (64), leaves (23), and sap (28) of maize were tested for their phosphate solubilization efficiency based on either growth or presence of a clear halo zone surrounding the colonies after 10 days of incubation on NBRIP solid medium (Table 1 and Figure 2). Seventy-nine bacterial isolates that grew on solid medium were not able to produce the halo that is typically observed after phosphate solubilization. Nineteen of the 79 non-halo-forming bacteria showed phosphate-solubilizing activity in NBRIP liquid medium (Table 1). Although the majority of the isolates were obtained from the roots (64), the number of PSBs from the three sources were similar $(15,19$, and 21, respectively, from roots, leaves, and sap). The re-inoculation of the non-halo forming isolates confirmed their inability to form halo in the solid medium (Table 1). Although the majority of the bacteria were pre-isolated from the roots (64), the number of PSB in liquid medium was similar among the three sources $(15,19$, and 19, respectively, from roots, leaves, and sap).
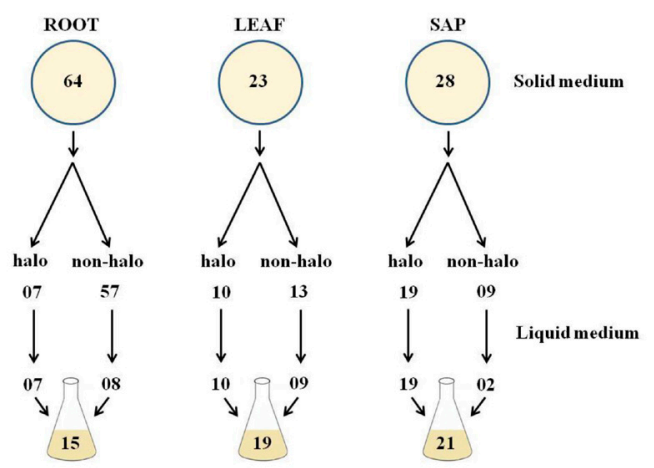

Figure 2. Schematic representation of PSB isolated from different tissues of maize showing the number of halo and non-halo forming isolates and the number of PSB in NBRIP solid and liquid medium, respectively.

Genetics and Molecular Research 16 (1): gmr16019294 
The SI varied significantly $(\mathrm{P} \leq 0.05)$ among the isolates (Table 1$)$. Forty-six isolates had poor SI (0-1.94), whereas only nine had moderate SI (2.0-3.71). Certain isolates that showed relatively low SI on solid medium exhibited higher phosphate-solubilizing activity in the liquid medium, which was similar to the SI values of halo-forming bacteria.

Table 1. Phosphate solubilizing efficiency of maize endophytic bacteria from different sources (sap, leaf, and root) cultivated on solid and liquid media supplemented with tricalcium phosphate (TCP).

\begin{tabular}{|c|c|c|c|c|c|c|}
\hline \multirow[t]{2}{*}{ Isolate } & \multirow[t]{2}{*}{ Source of inoculum } & \multicolumn{2}{|c|}{ NBRIP solid medium } & \multicolumn{3}{|c|}{ NBRIP liquid medium } \\
\hline & & SI (mm) & SE & $\mathrm{P}(\mathrm{mg} / \mathrm{L})$ & $\mathrm{pH}\left(\mathrm{H}_{2} \mathrm{O}\right)$ & Gluconic acid (mM) \\
\hline Control & - & - & - & $36.20 \mathrm{i}$ & $6.51 \mathrm{a}$ & - \\
\hline 1915 & Sap & $1.30 \mathrm{f}$ & low & $114.19 \mathrm{f}$ & $5.25 \mathrm{c}$ & $26.23 \mathrm{~g}$ \\
\hline 1916 & Sap & $1.76 \mathrm{e}$ & low & $174.52 \mathrm{~b}$ & $3.97 \mathrm{i}$ & $16.39 \mathrm{~g}$ \\
\hline 1917 & Sap & $1.69 \mathrm{e}$ & low & $150.47 \mathrm{~d}$ & $4.41 \mathrm{f}$ & $18.49 \mathrm{~g}$ \\
\hline 1918 & Sap & $1.39 \mathrm{f}$ & low & $111.35 \mathrm{~g}$ & $4.68 \mathrm{e}$ & $20.58 \mathrm{~g}$ \\
\hline 1919 & Sap & $3.71 \mathrm{a}$ & middle & $172.08 \mathrm{~b}$ & $4.09 \mathrm{~h}$ & $18.23 \mathrm{~g}$ \\
\hline 1921 & Sap & $1.64 \mathrm{e}$ & low & $174.47 \mathrm{~b}$ & $4.21 \mathrm{~g}$ & $20.43 \mathrm{~g}$ \\
\hline 1922 & Sap & $2.05 \mathrm{~d}$ & middle & $176.30 \mathrm{~b}$ & $3.97 \mathrm{i}$ & $16.33 \mathrm{~g}$ \\
\hline 1923 & Sap & $1.33 \mathrm{f}$ & low & $111.93 \mathrm{~g}$ & $5.50 \mathrm{~b}$ & $202.77 \mathrm{c}$ \\
\hline 1924 & Sap & $1.94 \mathrm{~d}$ & low & $166.27 \mathrm{c}$ & $3.99 \mathrm{i}$ & $20.42 \mathrm{~g}$ \\
\hline 1925 & Sap & $3.61 \mathrm{a}$ & middle & $132.88 \mathrm{e}$ & $4.73 \mathrm{e}$ & $194.59 \mathrm{c}$ \\
\hline 1928 & Sap & $1.50 \mathrm{f}$ & low & $169.23 \mathrm{~b}$ & $4.03 \mathrm{i}$ & $20.17 \mathrm{~g}$ \\
\hline 1929 & Sap & $2.88 \mathrm{~b}$ & middle & $165.01 \mathrm{c}$ & $3.99 \mathrm{i}$ & $20.63 \mathrm{~g}$ \\
\hline 1930 & Sap & $2.06 \mathrm{~d}$ & middle & $129.06 \mathrm{e}$ & $4.26 \mathrm{~g}$ & $18.32 \mathrm{~g}$ \\
\hline 1931 & Leaf & $1.42 \mathrm{f}$ & low & $134.21 \mathrm{e}$ & $4.23 \mathrm{~g}$ & $30.65 \mathrm{~g}$ \\
\hline 1932 & Leaf & $1.58 \mathrm{e}$ & low & $138.29 \mathrm{e}$ & $4.32 \mathrm{~g}$ & $44.67 \mathrm{~g}$ \\
\hline 1934 & Leaf & $1.55 \mathrm{e}$ & low & $80.32 \mathrm{~h}$ & $4.23 \mathrm{~g}$ & $188.31 \mathrm{c}$ \\
\hline 1935 & Leaf & $1.90 \mathrm{~d}$ & low & $137.54 \mathrm{e}$ & $4.28 \mathrm{~g}$ & $94.68 \mathrm{f}$ \\
\hline 1936 & Leaf & $1.94 \mathrm{~d}$ & low & $136.88 \mathrm{e}$ & $4.30 \mathrm{~g}$ & $142.50 \mathrm{~d}$ \\
\hline 1937 & Leaf & - & - & $135.90 \mathrm{e}$ & $4.24 \mathrm{~g}$ & $42.58 \mathrm{~g}$ \\
\hline 1939 & Leaf & $1.90 \mathrm{~d}$ & low & $135.92 \mathrm{e}$ & $4.28 \mathrm{~g}$ & $72.51 \mathrm{f}$ \\
\hline 1944 & Root & - & - & $129.71 \mathrm{e}$ & $4.77 \mathrm{e}$ & $143.96 \mathrm{~d}$ \\
\hline 1961 & Root & $2.00 \mathrm{~d}$ & middle & $124.33 \mathrm{f}$ & $4.54 \mathrm{f}$ & $20.43 \mathrm{~g}$ \\
\hline 1962 & Root & $2.42 \mathrm{c}$ & middle & $141.18 \mathrm{e}$ & $4.38 \mathrm{~g}$ & $22.78 \mathrm{~g}$ \\
\hline 1964 & Root & - & - & $117.14 \mathrm{f}$ & $4.82 \mathrm{e}$ & $167.17 \mathrm{~d}$ \\
\hline 1974 & Root & $1.00 \mathrm{~g}$ & low & $140.55 \mathrm{e}$ & $5.10 \mathrm{c}$ & $127.40 \mathrm{e}$ \\
\hline 1976 & Root & $1.62 \mathrm{e}$ & low & $169.50 \mathrm{~b}$ & $4.14 \mathrm{~h}$ & $27.16 \mathrm{~g}$ \\
\hline 1979 & Root & - & - & $159.09 \mathrm{c}$ & $5.14 \mathrm{c}$ & $148.18 \mathrm{~d}$ \\
\hline 1982 & Root & $1.00 \mathrm{~g}$ & low & $167.85 \mathrm{~b}$ & $4.61 \mathrm{f}$ & $178.47 \mathrm{c}$ \\
\hline 1984 & Root & - & - & $119.77 \mathrm{f}$ & $4.71 \mathrm{e}$ & $146.53 \mathrm{~d}$ \\
\hline 2006 & Sap & - & - & $158.18 \mathrm{c}$ & $5.67 \mathrm{~b}$ & $190.10 \mathrm{c}$ \\
\hline 2008 & Sap & - & - & $160.38 \mathrm{c}$ & $4.69 \mathrm{e}$ & $157.99 \mathrm{~d}$ \\
\hline 2009 & Sap & $1.71 \mathrm{e}$ & low & $164.23 \mathrm{c}$ & $5.12 \mathrm{c}$ & $183.71 \mathrm{c}$ \\
\hline 2010 & Sap & $1.49 \mathrm{f}$ & low & $175.38 \mathrm{~b}$ & $4.37 \mathrm{~g}$ & $165.60 \mathrm{~d}$ \\
\hline 2011 & Sap & $2.35 \mathrm{c}$ & middle & $181.32 \mathrm{a}$ & $4.13 \mathrm{~h}$ & 0 \\
\hline 2012 & Sap & $1.69 \mathrm{e}$ & low & $167.89 \mathrm{~b}$ & $4.16 \mathrm{~h}$ & $155.47 \mathrm{~d}$ \\
\hline 2013 & Sap & $1.69 \mathrm{e}$ & low & $155.11 \mathrm{~d}$ & $4.51 \mathrm{f}$ & $135.72 \mathrm{e}$ \\
\hline 2014 & Sap & $1.67 \mathrm{e}$ & low & $153.38 \mathrm{~d}$ & $4.53 \mathrm{f}$ & $264.17 \mathrm{~b}$ \\
\hline 2079 & Leaf & - & - & $185.55 \mathrm{a}$ & $3.90 \mathrm{i}$ & $177.38 \mathrm{c}$ \\
\hline 2080 & Leaf & - & - & $174.53 \mathrm{~b}$ & $4.26 \mathrm{~g}$ & $109.45 \mathrm{e}$ \\
\hline 2081 & Leaf & - & - & $148.47 \mathrm{~d}$ & $4.42 \mathrm{f}$ & $161.17 \mathrm{~d}$ \\
\hline 2082 & Leaf & - & - & $167.97 \mathrm{~b}$ & $4.94 \mathrm{~d}$ & $183.75 \mathrm{c}$ \\
\hline 2083 & Leaf & - & - & $154.11 \mathrm{~d}$ & $5.34 \mathrm{c}$ & $147.01 \mathrm{~d}$ \\
\hline 2084 & Leaf & $1.13 \mathrm{~g}$ & low & $120.42 \mathrm{f}$ & $4.80 \mathrm{e}$ & $324.08 \mathrm{a}$ \\
\hline 2085 & Leaf & - & - & $149.75 \mathrm{~d}$ & $4.96 \mathrm{~d}$ & $97.81 \mathrm{f}$ \\
\hline 2086 & Root & - & - & $104.07 \mathrm{~g}$ & $5.17 \mathrm{c}$ & $127.40 \mathrm{e}$ \\
\hline 2088 & Root & - & - & $179.39 \mathrm{a}$ & $4.73 \mathrm{e}$ & $171.46 \mathrm{c}$ \\
\hline 2096 & Leaf & - & - & $149.01 \mathrm{~d}$ & $4.98 \mathrm{~d}$ & $119.50 \mathrm{e}$ \\
\hline 2099 & Root & $1.64 \mathrm{e}$ & low & $139.57 \mathrm{e}$ & $4.25 \mathrm{~g}$ & $85.76 \mathrm{f}$ \\
\hline 2100 & Leaf & $1.80 \mathrm{e}$ & low & $158.63 \mathrm{c}$ & $4.03 \mathrm{i}$ & $156.21 \mathrm{~d}$ \\
\hline 2103 & Leaf & $1.21 \mathrm{f}$ & low & $134.14 \mathrm{e}$ & $4.41 \mathrm{f}$ & $30.47 \mathrm{~g}$ \\
\hline 2105 & Leaf & $2.06 \mathrm{~d}$ & middle & $155.19 \mathrm{~d}$ & $4.31 \mathrm{~g}$ & $195.12 \mathrm{c}$ \\
\hline 2106 & Root & $1.24 \mathrm{f}$ & low & $191.46 \mathrm{a}$ & $4.19 \mathrm{~h}$ & $136.70 \mathrm{e}$ \\
\hline 2108 & Root & - & - & $118.24 \mathrm{f}$ & $5.00 \mathrm{~d}$ & $61.80 \mathrm{f}$ \\
\hline 2110 & Leaf & - & - & $181.98 \mathrm{a}$ & $3.90 \mathrm{i}$ & $179.49 \mathrm{c}$ \\
\hline 2111 & Root & - & - & $176.33 \mathrm{~b}$ & $4.83 \mathrm{e}$ & $212.80 \mathrm{c}$ \\
\hline
\end{tabular}

Genetics and Molecular Research 16 (1): gmr16019294 
Mean values followed by the same alphabet do not differ by the Scott-Knott test at $5 \%$ probability. Control $=$ sterile liquid medium, $\mathrm{P}=$ phosphate. The phosphate solubilizing index (SI) and the solubilizing efficiency (SE) were measured after 10 days of incubation on solid medium; gluconic acid production was measured after 6 days; $\mathrm{pH}$ and phosphate solubilization in liquid medium (milligrams of phosphate per liter) were estimated after 9 days of incubation. Data are reported as means of three replicates.

\section{Phosphate solubilization by maize endophytic PSB in liquid NBRIP medium shows a negative correlation with the $\mathrm{pH}$ of the medium}

The values of phosphate solubilization for each isolate are expressed as the sum of the absolute values measured on the sixth and ninth days of incubation. There was a statistically significant difference $(\mathrm{P} \leq 0.05)$ for both, the values of phosphate-solubilizing activity and $\mathrm{pH}$ of the growth medium among the isolates (Table 1, Figure 1). The highest and lowest values of phosphorus solubilization were observed, respectively, for isolates 2106 (B. megaterium) and 1934 (Pantoea ananatis).

Pearson correlation was statistically significant $(\mathrm{P} \leq 0.05)$ between $\mathrm{P}$-solubilization and $\mathrm{pH}(\mathrm{R}=-0.38)$, and between the gluconic acid production and the lowering of the $\mathrm{pH}$ of the liquid medium at $6(\mathrm{R}=0.28)$ and 9 days $(\mathrm{R}=0.39)$. A comparison of the phosphatesolubilizing efficiencies of the isolates in solid and liquid medium, respectively, showed that the majority of bacteria exhibited low phosphate-solubilizing activity in both media (Table 1). The solubility values in the liquid medium, which indicates the relative efficiency of phosphate solubilization of the 55 isolates, are shown in the Figure 3.

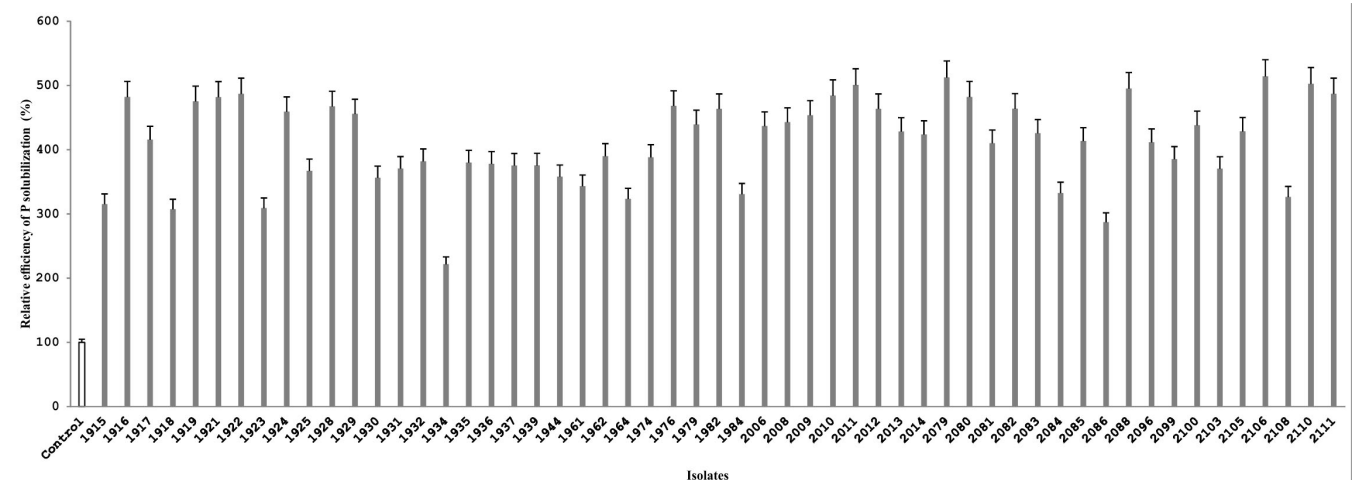

Figure 3. Relative phosphate-solubilizing efficiency of the maize endophytic bacterial isolates cultured in liquid medium with TCP as the sole source of phosphorus. Data (vertical bars) are reported as means \pm standard error of three replicates. The empty bar indicates the negative control (culture medium without bacterial inoculum).

\section{Quantification of organic acids revealed that gluconic acid was the predominant acid secreted by PSB}

The nature and amount of organic acids secreted by each bacterial isolate varied significantly $(\mathrm{P} \leq 0.05)$ (Figure 4$)$. The concentration of gluconic acid produced varied between 16.33 and $324.08 \mathrm{mM}$ (Table 1). While 5-ketogluconic acid was not detected in any

Genetics and Molecular Research 16 (1): gmr16019294 
of the isolates, gluconic acid was detected in most of the isolates, and acetic acid was detected in only one isolate (Figure 4).

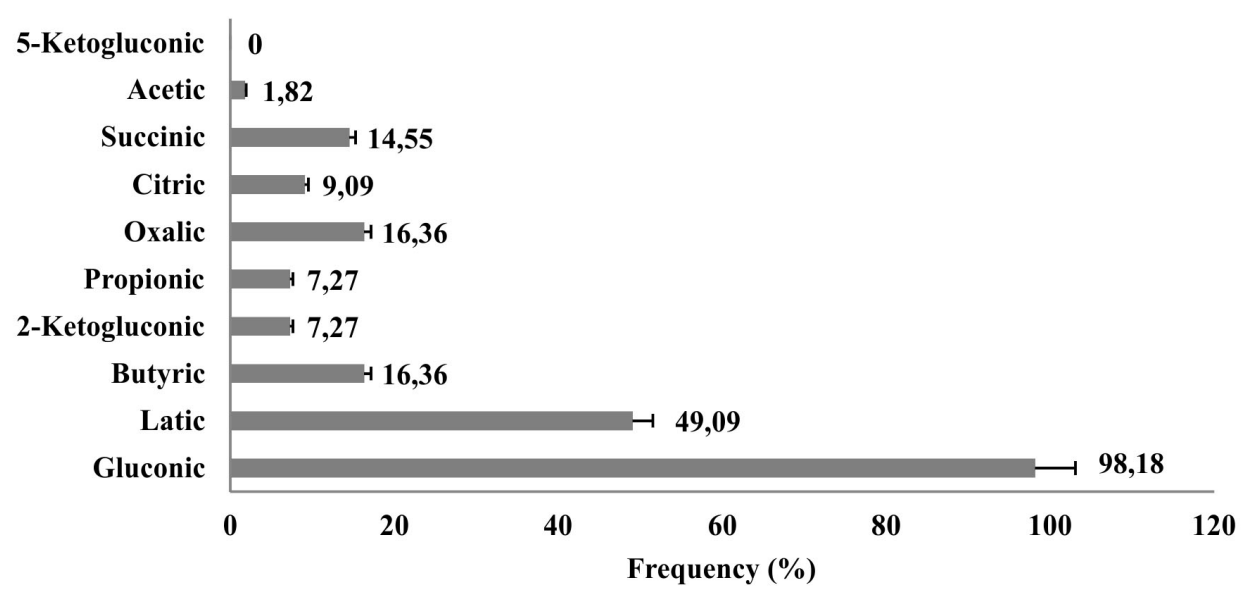

Figure 4. Relative amounts of organic acid produced by the maize endophytic bacterial isolates were determined by high-performance liquid chromatography with refractive index detection. Data (horizontal bars) are reported as means \pm standard error of three replicates.

The correlation between the association of phosphate-solubilization and the type of the acid produced was statistically significant $(\mathrm{P} \leq 0.05)$ only for oxalic acid at 9 days (Table 2$)$.

Table 2. Pearson correlation coefficient among amounts of soluble phosphate, acidity of medium, and amount of organic acid produced.

\begin{tabular}{|c|c|c|c|c|c|c|c|c|c|c|c|c|c|c|}
\hline & \multicolumn{4}{|c|}{ P-solubilization and $\mathrm{pH}$} & \multicolumn{10}{|c|}{ Organic acid production } \\
\hline & \multicolumn{2}{|c|}{6 days } & \multicolumn{2}{|c|}{9 days } & \multirow[t]{2}{*}{ Acetic } & \multirow[t]{2}{*}{ Butyric } & \multirow[t]{2}{*}{ Citric } & \multirow[t]{2}{*}{ Gluconic } & \multirow[t]{2}{*}{ 2-ketogluconic } & \multirow[t]{2}{*}{ Lactic } & \multirow[t]{2}{*}{ Oxalic } & \multirow[t]{2}{*}{ Propionic } & \multirow[t]{2}{*}{ Succinic } & \multirow{2}{*}{$\begin{array}{r}\text { Total } \\
\text { OA }^{1}\end{array}$} \\
\hline & $\mathrm{P}$ & $\mathrm{pH}$ & $P$ & $\mathrm{pH}$ & & & & & & & & & & \\
\hline $\mathrm{P}$ (6 days) & 1 & $-0.38^{*}$ & & & $\mathrm{nc}$ & $0.46^{\mathrm{ns}}$ & $0.41^{\mathrm{ns}}$ & $0.11^{\mathrm{ns}}$ & $-0.59^{\mathrm{ns}}$ & $-0.06^{\mathrm{ns}}$ & $0.44^{\mathrm{ns}}$ & $0.57^{\mathrm{ns}}$ & $0.21^{\mathrm{ns}}$ & $0.19^{\mathrm{ns}}$ \\
\hline $\mathrm{pH}$ (6 days) & & 1 & & & $\mathrm{nc}$ & $-0.02^{\mathrm{ns}}$ & $0.02^{\mathrm{ns}}$ & $0.28^{*}$ & $0.78^{\mathrm{ns}}$ & $-0.31^{\text {ns }}$ & $-0.37^{\mathrm{ns}}$ & $0.49^{\mathrm{ns}}$ & $-0.43^{\mathrm{ns}}$ & $0.14^{\mathrm{ns}}$ \\
\hline $\mathrm{P}$ (9 days) & & & 1 & $-0.38^{*}$ & $\mathrm{nc}$ & $0.19^{\mathrm{ns}}$ & $0.13^{\mathrm{ns}}$ & $0.07^{\mathrm{ns}}$ & $-0.19^{\mathrm{ns}}$ & $0.13^{\mathrm{ns}}$ & $0.76^{*}$ & $-0.42^{\mathrm{ns}}$ & $0.20^{\mathrm{ns}}$ & $0.12^{\mathrm{ns}}$ \\
\hline $\mathrm{pH}$ (9 days) & & & & 1 & $\mathrm{nc}$ & $-0.50^{\mathrm{ns}}$ & $-0.18^{\mathrm{ns}}$ & $0.39^{*}$ & $0.87^{\mathrm{ns}}$ & $-0.35^{\text {ns }}$ & $-0.43^{\text {ns }}$ & $0.13^{\text {ns }}$ & $-0.22^{\mathrm{ns}}$ & $0.15^{\text {ns }}$ \\
\hline
\end{tabular}

*Significant at $5 \%$ probability; ${ }^{\text {ns}}$ Not significant at $5 \%$ probability; Total $\mathrm{OA}^{1}$ : Total organic acid produced by the maize endophytic PSB; nc: no correlation, P: Phosphate.

\section{Molecular characterization of PSB revealed the presence of Bacillus and Enterobacteriaceae}

Partial sequencing of the 16S rRNA-encoding gene revealed that all the endophytic PSB isolates belonged to either the genus Bacillus $(29=54.5 \%)$ or to different species of Enterobacteriaceae $(25=45.5 \%)$. Twenty-two of the isolates were B. subtilis, and eleven isolates that belonged to Enterobacteriaceae were P. ananatis. The other bacterial species were Bacillus amyloliquefaciens, Bacillus methylotrophicus, B. megaterium, B. subtilis, Bacillus pumilus, and Enterobacter asburiae (Table 3).

Genetics and Molecular Research 16 (1): gmr16019294 
Table 3. Molecular identification using partial sequencing of the 16S rRNA-encoding gene of the PSB isolated from maize.

\begin{tabular}{|c|c|c|}
\hline Isolate & GenBank accession No. & Species identity $(99-100 \%)$ \\
\hline 1915 & KU165802 & Bacillus pumilus \\
\hline 1916 & KU189305 & Klebsiella pneumoniae \\
\hline 1917 & KU165806 & Enterobacter ludwigii \\
\hline 1918 & KU172428 & Bacillus subtilis \\
\hline 1919 & KU172427 & Bacillus subtilis \\
\hline 1921 & KU165807 & Enterobacter ludwigii \\
\hline 1922 & KU189301 & Pantoea ananatis \\
\hline 1923 & KU165803 & Bacillus pumilus \\
\hline 1924 & KU189306 & Klebsiella pneumoniae \\
\hline 1925 & KU189302 & Pantoea ananatis \\
\hline 1928 & KU189308 & Burkholderia gladioli \\
\hline 1929 & KU189309 & Klebsiella $\mathrm{sp}$ \\
\hline 1930 & KU189303 & Pantoea ananatis \\
\hline 1931 & KU172436 & Pantoea ananatis \\
\hline 1932 & KU172437 & Pantoea ananatis \\
\hline 1934 & KU172432 & Pantoea ananatis \\
\hline 1935 & KU165821 & Bacillus subtilis \\
\hline 1936 & KU172433 & Pantoea ananatis \\
\hline 1937 & KU172434 & Pantoea ananatis \\
\hline 1939 & KU165805 & Leclercia $\mathrm{sp}$ \\
\hline 1944 & KU189307 & Klebsiella pneumoniae \\
\hline 1961 & KU172429 & Pantoea dispersa \\
\hline 1962 & KU165810 & Bacillus subtilis \\
\hline 1964 & KU165811 & Bacillus subtilis \\
\hline 1974 & KU165812 & Bacillus subtilis \\
\hline 1976 & KU165820 & Bacillus subtilis \\
\hline 1979 & KU172438 & Pseudomonas $\mathrm{sp}$ \\
\hline 1982 & KU165813 & Bacillus subtilis \\
\hline 1984 & KU172430 & Pantoea dispersa \\
\hline 2006 & KU165818 & Bacillus sp \\
\hline 2008 & KU189304 & Pantoea ananatis \\
\hline 2009 & KU172426 & Bacillus subtilis \\
\hline 2010 & KU165808 & Enterobacter $\mathrm{sp}$ \\
\hline 2011 & KU165819 & Bacillus sp \\
\hline 2012 & KU172424 & Bacillus subtilis \\
\hline 2013 & KU172425 & Bacillus subtilis \\
\hline 2014 & KU165804 & Bacillus aerophilus \\
\hline 2079 & KU165822 & Bacillus subtilis \\
\hline 2080 & KU165823 & Bacillus subtilis \\
\hline 2081 & KU189310 & Bacillus thuringiensis \\
\hline 2082 & KU165824 & Bacillus subtilis \\
\hline 2083 & KU165825 & Bacillus subtilis \\
\hline 2084 & KU189311 & Bacillus subtilis \\
\hline 2085 & KU165826 & Bacillus subtilis \\
\hline 2086 & KU189312 & Bacillus amyloliquefaciens \\
\hline 2088 & KU165814 & Bacillus subtilis \\
\hline 2096 & KU189313 & Pseudomonas $\mathrm{sp}$ \\
\hline 2099 & KU165815 & Bacillus subtilis \\
\hline 2100 & KU189314 & Serratia $\mathrm{sp}$ \\
\hline 2103 & KU172435 & Pantoea ananatis \\
\hline 2105 & KU172431 & Pantoea dispersa \\
\hline 2106 & KU165809 & Bacillus megaterium \\
\hline 2108 & KU165816 & Bacillus subtilis \\
\hline 2110 & KU165827 & Bacillus subtilis \\
\hline 2111 & KU165817 & Bacillus subtilis \\
\hline
\end{tabular}

Genetics and Molecular Research 16 (1): gmr16019294 


\section{DISCUSSION}

In the present study, we demonstrated the in vitro phosphate-solubilizing activity of endophytic PSB from maize by dissolution of TCP. The selected PSB could potentially be used as bioinoculants to improve phosphorus uptake and maize yield.

The correlation between phosphate-solubilizing activity and low $\mathrm{pH}$ of the growth medium was expected since the ability of PSB to convert insoluble phosphorus to a soluble form is directly related to the release of organic acids in the medium (Omar, 1998; Narula et al., 2000; Whitelaw, 2000; Pérez et al., 2007). Similar results were also reported by Chen et al. (2006). The phosphate-solubilizing efficiency is also dependent on the medium used to select the PSB. However, the source of insoluble phosphate in the culture medium is a major issue of controversy regarding the isolation of true PSB.

Although the formation of a clear halo zone around colonies on NBRIP medium is a good preliminary criterion for selecting isolates exhibiting phosphate-solubilizing activity, it should not be considered as the sole test for determining phosphate solubilization. Certain strains that could not solubilize phosphate on the agar plate showed efficient phosphate solubilization in the liquid medium with the same phosphate sources (Nautiyal, 1999; Bashan et al., 2013; Sharma et al., 2013). In our study, among the sixty bacterial isolates that were unable to solubilize phosphate on solid medium, nineteen showed phosphate-solubilizing activity in the liquid medium.

According to Whitelaw (2000), the size of both the halo and the colony correlates with the efficiency of phosphate solubilization. In this study, some isolates that showed relatively low SI on solid medium exhibited phosphate-solubilizing activity in the liquid medium similar to those of the halo-forming bacteria. This result may be explained by the fact that the diffusion of the secreted organic acid depends on the nature of the acid produced and the culture medium (Marra et al., 2012).

According to Bashan et al. (2013), methods using TCP are relatively weak and unreliable for isolating and testing PSB as although it usually identifies many putative strains, further tests may reveal that they are false positives for phosphorus solubilization. Other compounds have also been tested for PSB identification in vitro, such as iron phosphate $\left(\mathrm{FePO}_{4}\right)$, aluminum phosphate $\left(\mathrm{AlPO}_{4}\right)$, and several calcium phosphates. However, they are even less soluble than TCP in water (Bashan et al., 2013). Therefore, the authors of the study concluded that no metal-phosphate compound should be used for selecting PSB, especially because soils greatly vary in $\mathrm{pH}$ and chemical composition. They suggested that the choice of the metal-phosphate substrate for identifying putative PSBs should depend on the type of the soil where the PSB would be used. However, Silva Filho and Vidor (2001) reported a low incidence of $\mathrm{AlPO}_{4}$-solubilizing bacteria among isolates previously identified as efficient solubilizers of TCP. Thus, the phosphate-solubilizing activity is dependent on the medium used to select the PSB, and the choice of the phosphate source should depend on the purpose of the study. We used TCP-containing medium in our study as we intended to select rock phosphate-solubilizing endophytic bacteria that would be used in soil rich in calcium magnesium carbonate $\left[\mathrm{CaMg}\left(\mathrm{CO}_{3}\right)_{2}\right]$ or soil fertilized with rock phosphate from the hydroxyapatite group $\left[\mathrm{Ca}_{5}\left(\mathrm{PO}_{4}\right)_{3} \mathrm{OH}\right]$. The acidity of the tropical zone soil is corrected with the application of calcium carbonate to the soil surface. Thus, the phosphate group of the fertilizer, which is applied to the soil, also reacts with calcium forming $\mathrm{Ca}_{3}\left(\mathrm{PO}_{4}\right)_{2}$. In addition, since the solubilization of iron or aluminum-complexed phosphate is lower than that of calcium-

Genetics and Molecular Research 16 (1): gmr16019294 
complexed phosphate, the use of rock phosphate-solubilizing bacteria is a good choice to increase the availability of phosphorus that has accumulated as $\mathrm{Ca}_{3}\left(\mathrm{PO}_{4}\right)_{2}$ in the soil (Hameeda et al., 2008). In addition, the constant use of synthetic fertilizers has adversely affected the environment, besides increasing the cost of production. The cheaper and direct use of rock phosphate solubilizers is an interesting alternative for poor farmers and it also supports ecofriendly farming and sustainable agriculture (Smalberger et al., 2010).

Regarding the production of organic acids, the type of acid that is produced by each bacterial species depends on complex parameters such as the nutritional and physiological status of the culture and the concentration and composition of nutrients in the medium (Chen et al., 2006; Pérez et al., 2007). Gluconic acid and keto-gluconic acid are the two most common organic acids produced by PSB (Goldstein, 1986). In other studies, gluconic, 2-ketogluconic, oxalic, succinic, citric, and lactic acids were among the most frequent metabolites produced by PSB (Rodríguez and Fraga 1999; Khan et al., 2010; Behera et al., 2016). Various authors found that the acids most frequently produced by PSB are the gluconic acid, 2-ketogluconic, oxalic, succinic, citric, and lactic (Behera et al., 2016). We found significant correlation between organic acid production and reduction of the $\mathrm{pH}$ of the medium only for gluconic acid.

In this study, all endophytic PSB isolates were from the genus Bacillus and different species of Enterobacteriaceae. These isolates belong to bacterial genera previously demonstrated to have the ability of solubilizing different sources of mineral phosphates (Murugan and Ramesh, 2013). Comparison of data presented in Tables 1 and 3 shows that there is no relationship between the source of the isolates (leaves, sap or roots) or the taxonomic group, and the efficiency of phosphate solubilization. We have previously shown that PSB species from these bacterial groups were also isolated from the soil of maize rhizosphere (Oliveira et al., 2009; Gomes et al., 2014). This indicates that these PSB may be capable of developing a connection between the plant tissue and the rhizosphere soil as mentioned by Farrar et al. (2014). All isolates of the present study belong to bacterial groups that have been previously demonstrated to solubilize different sources of mineral phosphates (Murugan and Ramesh, 2013). Kim et al. (1998) showed that Enterobacter solubilizes hydroxyapatite and organic phosphate, and Mohammadi (2012) found that mixed cultures of Bacillus, Streptomyces, and Pseudomonas are more effective in mineralizing organic phosphate. Different species of Bacillus and Pantoea have been extensively reported as efficient agents for solubilizing insoluble inorganic phosphate from different sources, including $\mathrm{Ca}_{3}\left(\mathrm{PO}_{4}\right)_{2},\left[\mathrm{Ca}_{5}\left(\mathrm{PO}_{4}\right)_{3} \mathrm{OH}\right]$, and rock phosphate (Pérez et. al., 2007; Oliveira et al., 2009; Kumar et al., 2014; da Silva et al., 2015). In fact, numerous Bacillus-based and Pantoea sp inoculants that produce phytase or organic acids have already been developed and patented (Kim et al., 1998; Mohammadi, 2012; Kumar et al., 2014).

Two isolates from the sap $(1919=B$. subtilis and $1925=P$. ananatis $)$ showed the highest SI (3.71 and $3.61 \mathrm{~mm}$, respectively) in NBRIP solid medium (Tables 1 and 3). However, none of the isolates was efficient in solubilizing phosphate in NBRIP liquid medium. Four Bacillus isolates were very efficient in solubilizing phosphate in the liquid medium $(>180.00$ $\mathrm{mg} / \mathrm{L}$ ). Interestingly, three of these isolates were previously identified to be non-phosphatesolubilizing candidates on the solid medium (Table 1).

In conclusion, endophytic PSB isolated from maize grown in the Brazilian Cerrado soil exhibited different levels of phosphate-solubilizing activity and gluconic acid production. The gluconic acid production was prevalent in all the PSB studied, and species of the genus Bacillus were the most efficient phosphate solubilizers. Bacillus species are easily isolated

Genetics and Molecular Research 16 (1): gmr16019294 
from maize, suggesting an evolutionary relationship between these organisms (Figueiredo et al., 2009). This indicates that Bacillus species may be used for selecting the most adapted and efficient phosphate solubilizers from maize. This is the first report on phosphate solubilizer endophytic bacteria from tropical maize as potential biofertilizers.

\section{Conflicts of interest}

The authors declare no conflict of interest.

\section{ACKNOWLEDGMENTS}

Research supported by grants from Universidade Federal de São João Del Rei (UFSJ) to Crísia Santos de Abreu, Fundação de Amparo à Pesquisa do Estado de Minas Gerais (FAPEMIG), Conselho Nacional de Desenvolvimento Científico e Tecnológico (CNPq), Embrapa Milho e Sorgo (CNPMS), and Universidade Federal de Minas Gerais (UFMG).

\section{REFERENCES}

Araújo JM, Silva AC and Azevedo JL (2000). Isolation of endophytic actinomycetes from roots and leaves of maize (Zea mays L.). Braz. Arch. Biol. Technol. 43: 447-451. http://dx.doi.org/10.1590/S1516-89132000000400016

Baliah NT, Pandiarajan G and Kumar BM (2016). Isolation, identification and characterization of phosphate solubilizing bacteria from different crop soils of Srivilliputtur Taluk, Virudhunagar District, Tamil Nadu. Trop. Ecol. 57: 465-474.

Bashan Y, Kamnev AA and Bashan LE (2013). A proposal for isolating and testing phosphate-solubilizing bacteria that enhance plant growth. Biol. Fertil. Soils 49: 1-2. http://dx.doi.org/10.1007/s00374-012-0756-4

Behera BC, Singdevsachan SK, Mishra RR, Sethi BK, et al. (2016). Phosphate solubilising bacteria from mangrove soils of Mahanadi river delta, Odisha, India. World J. Agricult. Res 4: 18-23.

Berraquero FR, Baya AM and Cormenzana AR (1976). Estabelecimiento de índices para el estudio de la solubilización de fosfatos por bacterias del suelo. Ars. Pharmaceutica 17: 399-406.

Chen YP, Rekha PD, Arun AB, Shen FT, et al. (2006). Phosphate solubilizing bacteria from subtropical soil and their tricalcium phosphate solubilizing abilities. Appl. Soil Ecol. 34: 33-41. http://dx.doi.org/10.1016/j.apsoil.2005.12.002

da Silva JF, Barbosa RR, de Souza AN, da Motta OV, et al. (2015). Isolation of Pantoea ananatis from sugarcane and characterization of its potential for plant growth promotion. Genet. Mol. Res. 14: 15301-15311. http://dx.doi. org/10.4238/2015.November.30.6

Edwards CL, Maguire RO, Alley MM, Thomason WE, et al. (2016). Plant-available phosphorus after application of synthetic chelating agents. Commun. Soil Sci. Plant Anal. 47: 433-446.

Farrar K, Bryant D and Cope-Selby N (2014). Understanding and engineering beneficial plant-microbe interactions: plant growth promotion in energy crops. Plant Biotechnol. J. 12: 1193-1206. http://dx.doi.org/10.1111/pbi.12279

Ferreira DF (2010). SISVAR, Sistema de análise de variância. Versão 5.3. Universidade Federal de Lavras, Lavras.

Figueiredo JEF, Gomes EA, Guimarães CT, de Paula Lana UG, et al. (2009). Molecular analysis of endophytic bacteria from the genus Bacillus isolated from tropical maize (Zea mays L.). Braz. J. Microbiol. 40: 522-534. http://dx.doi. org $/ 10.1590 / \mathrm{S} 1517-83822009000300014$

Gaiero JR, McCall CA, Thompson KA, Day NJ, et al. (2013). Inside the root microbiome: bacterial root endophytes and plant growth promotion. Am. J. Bot. 100: 1738-1750. http://dx.doi.org/10.3732/ajb.1200572

Goldstein AH (1986). Bacterial solubilization of mineral phosphates: Historical perspective and future prospects. Am. J. Altern. Agric. 1: 51-57. http://dx.doi.org/10.1017/S0889189300000886

Gomes EA, Silva UC, Marriel IE, Oliveira CA, et al. (2014). Rock phosphate solubilizing microorganisms isolated from maize rhizosphere soil. Rev. Bras. Milho Sorgo 13: 69-81. http://dx.doi.org/10.18512/1980-6477/rbms.v13n1p69-81

Gurikar C, Naik MK and Sreenivasa MY (2016). Azotobacter: PGPR Activities with special reference to effect of pesticides and biodegradation. In: Microbial Inoculants in Sustainable Agricultural Productivity: Research Perspectives. (Singh DP, Singh HB, Prabha R, eds.). Springer, New Delhi.

Hameeda B, Harini G, Rupela OP, Wani SP, et al. (2008). Growth promotion of maize by phosphate-solubilizing bacteria isolated from composts and macrofauna. Microbiol. Res. 163: 234-242. http://dx.doi.org/10.1016/j.micres.2006.05.009

Genetics and Molecular Research 16 (1): gmr16019294 
Hinsinger P (2001). Bioavailability of soil inorganic P in the rhizosphere as affected by root-induced chemical changes: a review. Plant Soil 237: 173-195. http://dx.doi.org/10.1023/A:1013351617532

Johnston-Monje D and Raizada MN (2011). Conservation and diversity of seed associated endophytes in Zea across boundaries of evolution, ethnography and ecology. PLoS One 6: e20396 http://dx.doi.org/10.1371/journal. pone.0020396.

Karpagam T and Nagalakshmi PK (2014). Isolation and characterization of phosphate solubilizing microbes from agricultural soil. Int. J. Curr. Microbiol. Appl. Sci 3: 601-614.

Khan MS, Zaidi A, Ahemad M, Oves M, et al. (2010). Plant growth promotion by phosphate solubilizing fungi - current perspective. Arch. Agron. Soil Sci. 56: 73-98. http://dx.doi.org/10.1080/03650340902806469

Kim KY, Jordan D and McDonald GA (1998). Effect of phosphate solubilizing bacteria and vesicular-arbuscular mycorrhizae on tomato growth and soil microbial activity. Biol. Fertil. Soils 26: 79-87. http://dx.doi.org/10.1007/ $\underline{\mathrm{s} 003740050347}$

Kumar A, Choudhary CS, Paswan D, Kumar B, et al. (2014). Sustainable way for enhancing phosphorus efficiency in agricultural soils through phosphate solubilizing microbes. Asian J. Soil Sci 9: 300-310. http://dx.doi.org/10.15740/ HAS/AJSS/9.2/300-310

Marra LM, Soares CRS, Oliveira SM, Ferreira PAA, et al. (2012). Biological nitrogen fixation and phosphate solubilization by bacteria isolated from tropical soils. Plant Soil 357: 289-307. http://dx.doi.org/10.1007/s11104-012-1157-z

Mohammadi K (2012). Phosphorus Solubilizing Bacteria: Occurrence, mechanisms and their role in crop production. Resources Environ 2: 80-85.

Murugan A and Ramesh S (2013). Replacing super phosphate with tricalcium phosphate enhances Bhendi growth Inter. J. Innovative Res. Sci. Eng. Techn 2: 4478-4486.

Narula N, Kumar V, Behl RK, Deubel A, et al. (2000). Effect of P solubilizing Azotobacter chroococcum on N, P, K uptake in P responsive wheat genotypes grown under green house conditions. J. Plant Nutr. Soil Sci. 163: 393-398. http://dx.doi.org/10.1002/1522-2624(200008)163:4<393::AID-JPLN393>3.0.CO;2-W

Nautiyal CS (1999). An efficient microbiological growth medium for screening phosphate solubilizing microorganisms. FEMS Microbiol. Lett. 170: 265-270. http://dx.doi.org/10.1111/j.1574-6968.1999.tb13383.x

Novais RF, Smyth TJ and Nunes FN (2007). Fósforo. In: Fertilidade do solo. (Novais RF, Alvarez VVH, Barros NF, Fontes RLF, Cantarutti RB, Neves JCL, eds.). Sociedade Brasileira de Ciências do Solo, Viçosa, 471-550.

Oliveira CA, Alves VM, Marriel IE, Gomes EA, et al. (2009). Phosphate solubilizing microorganisms isolated from rhizosphere of maize cultivated in an oxisol of the Brazilian Cerrado biome. Soil Biol. Biochem. 41: 1782-1787. http://dx.doi.org/10.1016/j.soilbio.2008.01.012

Omar SA (1998). The role of rock-phosphate-solubilizing fungi and vesicular-arbuscular-mycorrhiza (VAM) in growth of wheat plants fertilized with rock phosphate. World J. Microb. Biot 14: 211-218. http://dx.doi. org/10.1023/A:1008830129262

Park JH, Bolan N, Megharaj M and Naidu R (2011). Isolation of phosphate solubilizing bacteria and their potential for lead immobilization in soil. J. Hazard. Mater. 185: 829-836. http://dx.doi.org/10.1016/j.jhazmat.2010.09.095

Pérez E, Sulbarán M, Ball MM, Yarzábal LA, et al. (2007). Isolation and characterization of mineral phosphate-solubilizing bacteria naturally colonizing a limonitic crust in the south-eastern Venezuelan region. Soil Biol. Biochem. 39: 29052914. http://dx.doi.org/10.1016/j.soilbio.2007.06.017

Pinto FA, Souza ED, Paulino HB, Curi N, et al. (2013). P-sorption and desorption in Savanna Brazilian soils as a support for phosphorus fertilizer management. Cienc. Agrotec. 37: 521-530. http://dx.doi.org/10.1590/S141370542013000600005

Rodríguez H and Fraga R (1999). Phosphate solubilizing bacteria and their role in plant growth promotion. Biotechnol. Adv. 17: 319-339. http://dx.doi.org/10.1016/S0734-9750(99)00014-2

Rosenblueth M and Martínez-Romero E (2006). Bacterial endophytes and their interactions with hosts. Mol. Plant Microbe Interact. 19: 827-837. http://dx.doi.org/10.1094/MPMI-19-0827

Sharma SB, Sayyed RZ, Trivedi MH and Gobi TA (2013). Phosphate solubilizing microbes: sustainable approach for managing phosphorus deficiency in agricultural soils. Springerplus 2: 587-601. http://dx.doi.org/10.1186/2193-1801-2-587

Silva Filho GN and Vidor C (2001). Atividade de microrganismos solubilizadores de fosfatos na presença de nitrogênio, ferro, cálcio e potássio. Pesqui. Agropecu. Bras. 36: 1495-1508. http://dx.doi.org/10.1590/S0100-204X2001001200007

Smalberger SA, Chien SH, Singh U and Julio H (2010). Relative agronomic effectiveness of phosphate rock compared with triple superphosphate for initial canola, wheat, or ryegrass, and residual wheat in two acid soils. Soil Sci. 175: 36-43. http://dx.doi.org/10.1097/SS.0b013e3181c752dd

Whitelaw MA (2000). Growth promotion of plants inoculated with phosphate-solubilizing fungi. Adv. Agron. 69: 99-151. http://dx.doi.org/10.1016/S0065-2113(08)60948-7

Genetics and Molecular Research 16 (1): gmr16019294 